\title{
DEVELOPMENT AND PHYSICOCHEMICAL CHARACTERIZATION OF ARTISANAL MINAS CANASTRA CHEESE PRODUCED WITH CYNARA CARDUNCULUS L.
}

\section{Desenvolvimento e caracterização físico-química do queijo minas artesanal canastra produzido com Cynara cardunculus $\mathrm{L}$.}

\author{
Eduardo José Borges ${ }^{1 *}$, Mariana Torres de Castro ${ }^{I}$, Amanda Rodrigues Franco de Freitas ${ }^{1}$, \\ Ana Cláudia Borges ${ }^{2}$, Priscila Alonso dos Santos ${ }^{3}$
}

\begin{abstract}
Artisanal Minas Canastra cheese (AMC) is produced from raw milk, with the addition of coagulant and endogenous culture. The cheese is then shaped, handpressed, dry-salted, and matured for twenty-two days. Cynara cardunculus L. (C.C.L.) is a perennial plant from the Mediterranean region, and enzymes used as milk-coagulating agents (cardosins) can be obtained from its dried flowers. The present study aimed at developing and evaluating the physicochemical characteristics of AMC cheese, produced with three different concentrations of C.C.L. The experimental cheeses exhibited proteolysis extension and depth indexes higher to traditional Canastra cheese. The $\mathrm{pH}$ and moisture content were not influenced by the type of coagulant. Moreover, the cheeses obtained using the plant coagulant $\left(\mathrm{T}^{1}, \mathrm{~T}^{2}\right.$, and $\left.\mathrm{T}^{3}\right)$ exhibited a softer texture $(3.78 \mathrm{~N}, 3.70 \mathrm{~N}$, and $3.31 \mathrm{~N}$, respectively) when compared with the traditional cheese $(6.47 \mathrm{~N})$, during a 43 -day period of maturation. The fracturability of the cheese control after such period $(7.12 \mathrm{~N})$ also showed to be considerably higher than all of the treatments $(3.72 \mathrm{~N}, 3.70 \mathrm{~N}$, and $3.31 \mathrm{~N})$. These results indicate the possibility of producing cheeses with desirable sensorial characteristics within the minimum required maturation period, following the typical physicochemical parameters of AMC cheese.
\end{abstract}

Keywords: raw milk; thistle; maturation; texture; Canastra cheese.

1 Instituto Federal do Triângulo Mineiro, Campus Ituiutaba, Rua Belarmino Vilela Junqueira s/nº, Novo Tempo 2, 38305-200, Ituiutaba, MG, Brasil. E-mail:eduardoborges@iftm.edu.br

2 Faculdade de Ciências Integradas do Pontal, Ituiutaba, MG, Brasil.

3 Instituto Federal Goiano, Campus Rio Verde, Rio Verde, GO, Brasil.

* Autor para correspondência.

Recebido / Received: 18/09/2018

Aprovado / Approved: 30/10/2018 


\section{RESUMO}

O queijo Minas artesanal Canastra é um queijo produzido a partir de leite cru, com adição do coalho e do "pingo", o fermento natural endógeno. É então enformado, prensado à mão, salgado a seco e maturado por um período de 22 dias. A Cynara cardunculus L. é uma planta perene típica da região do mediterrâneo e, de suas flores secas, obtêm-se as enzimas (cardosinas) utilizadas como agentes coagulantes do leite. Pretendeu-se com o presente estudo desenvolver e avaliar as características físico-químicas do queijo Minas artesanal Canastra, produzido com três diferentes concentrações de Cynara cardunculus L. Os queijos mostraram índices de extensão e de profundidade da proteólise superiores ao queijo Canastra tradicional. Os parâmetros de $\mathrm{pH}$ e umidade não foram influenciados pelo tipo de coagulante. Ademais, os queijos obtidos com o coagulante vegetal $\left(\mathrm{T}^{1}, \mathrm{~T}^{2}\right.$ e $\left.\mathrm{T}^{3}\right)$ exibiram, respectivamente, uma textura mais macia $(3,78 \mathrm{~N}, 3,70 \mathrm{~N}$ e $3,31 \mathrm{~N})$ em comparação ao queijo tradicional $(6,47 \mathrm{~N})$, ao longo de 43 dias de maturação. A fraturabilidade do controle aos 43 dias $(7,12 \mathrm{~N})$ também se mostrou superior a todos os tratamentos $(3,72 \mathrm{~N}, 3,70 \mathrm{~N}$ e $3,31 \mathrm{~N})$. Estes resultados denotam a possibilidade de se produzir queijos com características sensoriais desejáveis dentro do período mínimo de maturação exigido e em conformidade com os parâmetros físico-químicos típicos do queijo Minas artesanal Canastra.

Palavras-chave: leite cru; cardo ; maturação; textura; queijo Canastra.

\section{INTRODUCTION}

Cheese production is rooted in the culture of the State of Minas Gerais and plays an essential role in the social organization of rural families and the local productive arrangement. Seven micro-regions are currently recognized, by an indication of origin (IP), as Artisanal Minas cheese-producing regions (BRASIL, 2013). According to the chronological order of registration in the State Institute of Agriculture (IMA), State Historic and Artistic Heritage Institute (IEPHA), Brazil's National Historical and Artistic Heritage Institute (IPHAN), and/ or the National Institute for the Protection of Industrial Property (INPI), these regions are comprised of: Araxá, Cerrado (Alto Paranaíba), Serro, Serra da Canastra, Campo das Vertentes, Triângulo Mineiro, and Serra do Salitre (IMA, 2002, 2003, 2004, 2007, 2009, 2014a, b; MATOS, 2016).
Considering the edaphoclimatic characteristics of each region, including climate, rainfall, relief, wind, altitude, soil, and pastureland, cheeses with unique sensorial profiles have been produced, including the Artisanal Minas Canastra cheese (AMC). This cheese is produced from raw milk, with the addition of coagulant and endogenous natural culture, which is obtained from milk whey of the cheese that was manufactured on the previous day. The cheese is then shaped, subjected to manual pressing, dry-salted, and matured for a minimum period of 22 days (IMA, 2013). It is considered a cheese of semi-hard consistency and compact texture, with yellowish-white color, a thin yellowish crust, without cracks, and a slightly acidic and non-spicy flavor (ALMEIDA; FERNANDES, 2004).

In accordance with the Use Regulation, established by the Canastra Cheese Producers Association - APROCAN, the product 
receives the following classifications, according to its dimensions: Canastra Cheese, produced in bottomless molds with $17.0 \mathrm{~cm}$ in diameter and $7.0 \mathrm{~cm}$ high (900 to $1,300 \mathrm{~g}$ ); Merendeiro Canastra Cheese, manufactured in bottomless frames with $10.0 \mathrm{~cm}$ in diameter and $6.0 \mathrm{~cm}$ in height (300 to $400 \mathrm{~g}$ ), and Royal Canastra Cheese, produced in bottomless molds with 28.0 to $35.0 \mathrm{~cm}$ in diameter and height between 10.0 and $18.0 \mathrm{~cm}$ $(5,000$ to $7,000 \mathrm{~g})$ (APROCAN, 2014).

According to Silva (2007), the use of industrial, liquid, chymosin-based coagulant, of microbial origin, is practiced in $85 \%$ of the properties of the Serra da Canastra region. The use of industrial powdered coagulant represents the remaining $15 \%$. The type of coagulant used in cheese production can influence the sensory characteristics of the final product, as the proteolysis extension index is closely related to the enzymatic activity of the coagulant (TOFALO et al., 2015). Delgado et al. (2015) stated that cheeses produced with plant coagulant from Cynara cardunculus L. tend to develop more intense proteolysis, giving rise to a more homogeneous structure, increasing creaminess and conferring lightness to the cheese.

Cynara cardunculus L. is a typical perennial plant of the Mediterranean region, originated from the crossing of species belonging to the family Asteraceae. The enzymes (cardosins), used as coagulant agents in sheep's milk, are obtained from the plant's dried flowers, which constitute the basis for the production of several regional Portuguese cheeses with Protected Origin Designation (POD) and Protected Geographical Indication (PGI), such as the Serra da Estrela, Azeitão, and Nisa cheeses, and Spanish cheeses, such as La Serena, Los Pedroches, and Torta Del Casar cheeses (AMMAR et al., 2015; DELGADO et al., 2015; MARABUTO et al., 2017).

Although in the face of a promising scenario, initiatives that contribute to the development of Brazilian artisanal cheeses with new textures, flavors, and sensations, aiming to increase the diversity of supply and promote the appreciation of the artisanal product with a certification of origin, are rare. Considering this context, the effects concerning the substitution of commercial liquid coagulant by Cynara cardunculus L. extract during artisanal Minas cheese Canastra manufacturing were investigated. Thus, the present study was carried out to develop and evaluate the physicochemical characteristics of AMC cheese produced with Cynara cardunculus L.

\section{MATERIALS AND METHODS}

\section{Cheese production}

The experiment was conducted between April and June of 2016 on a rural property located in the county of Tapiraí/MG, Brazil. The coordinates remit to $19^{\circ} 50^{\prime} 57.84^{\prime \prime}$ latitude and 46 $06^{\circ} 26.93$ " longitude, at an altitude of $1,009 \mathrm{~m}$. The cheeses were produced using raw, freshly-milked bovine milk. A total of $40.0 \mathrm{~mL}$ of HA-LA ${ }^{\circledR}$ commercial liquid coagulant, diluted in 100 $\mathrm{mL}$ of endogenous culture, was added to $80.0 \mathrm{~L}$ of milk at $32{ }^{\circ} \mathrm{C}$. After coagulation (approximately 1 hour), the consistent curd was cut and subjected to homogenization for 5 minutes, and the excess whey was then removed. Next, the cheese mass was placed in molds of $10.0 \mathrm{~cm}$ in diameter by $12.0 \mathrm{~cm}$ in height and pressed manually. The cheeses were dry-salted for 8 hours using coarse salt. Afterward, they were turned over and salted again, remaining so until the next morning. Finally, the cheesecloth was wiped, obtaining the control (C). Twelve Merendeiro type cheeses were produced, which were submitted to maturation at room temperature in the cheese factory itself, on 
wooden boards, for periods of $0,21,42$, and 63 days. Throughout maturation, the cheeses were "rinsed" (cheesecloth wiping with the aid of abrasive material) weekly and turned at 24-hour intervals. Regarding the employed treatments, 0.4 g.L ${ }^{-1}\left(\mathrm{~T}^{1}\right), 0.6$ g.L $\mathrm{L}^{-1}$ $\left(\mathrm{T}^{2}\right)$ and 0.8 g.L. $\mathrm{L}^{-1}\left(\mathrm{~T}^{3}\right)$ of desiccated Cynara cardunculus L. were utilized, acquired from the School of Agriculture (Escola Superior Agrária) in Viseu - Portugal. The flowers were previously hydrated and macerated in $200 \mathrm{~mL}$ of water, remaining at rest for 1 hour at $30 \pm 2{ }^{\circ} \mathrm{C}$, and then filtered. The obtained extract was diluted in 100 $\mathrm{mL}$ of endogenous culture and added to the milk. Coagulation occurred in 1 h30 and proceeded as in the development of the control (C). Thirty-six cheeses with approximately $500 \mathrm{~g}$ each were produced, with three repetitions per treatment/time.

\section{Sample collection and preparation}

Four samplings were carried out at 0 , 21,42 , and 63 days of maturation, totaling twelve cheeses per collection. Due to the time required to transport the samples, all determinations were initiated the day after collection, completing 1, 22, 43, and 64 days of cheese production, in accordance with the Use Regulation (APROCAN, 2014). The cheeses were cut into blocks sized at $20.0 \mathrm{~mm}$ in length, depth, and width for texture inference. The remaining samples were crushed in a multiprocessor, packed in previously identified polyethylene bags, and stored at $7 \pm 2{ }^{\circ} \mathrm{C}$ during the analyses.

\section{Physicochemical analyses}

The $\mathrm{pH}$ was determined using a $\mathrm{pH}$ meter (mPA-210 Central Brazil) by direct introduction of the electrode in $10.0 \mathrm{~g}$ of sample, previously diluted in $20.0 \mathrm{~mL}$ of distilled water (BRASIL, 2006). The mois- ture content was assessed employing the gravimetric method (BRASIL, 2006).

\section{Texture}

In order to analyze texture, nine blocks of cheese, sized at $20.0 \mathrm{~mm}$ in length, depth, and width, were utilized, in which the parameters firmness (g) and fracturing (g) were evaluated. The texture profile of the Artisanal Minas Canastra cheese samples was assessed using a texturometer (CT3 Pro CT V 1.5 Build - Brookfield Engineering Labs. Inc.) with a five-kilogram loading cell equipped with Texture Pro ${ }^{\circledR}$ software for data analysis. The samples were compressed twice using an acrylic cylindrical probe with $75.0 \mathrm{~mm}$ in diameter, according to an adaptation of the methodology described by Delgado et al. (2015). The employed conditions comprised the following: test type, TPA; pre-test velocity, $2.0 \mathrm{~mm} . \mathrm{s}^{-1}$; test velocity, $1.0 \mathrm{~mm} . \mathrm{s}^{-1}$; post-test velocity, $1.0 \mathrm{~mm} . \mathrm{s}^{-1}$; compression distance, $9.0 \mathrm{~mm}$, and force threshold, $5.0 \mathrm{~g}$.

\section{Proteolysis}

The proteolysis extension index (PEI) and the proteolysis depth index (PDI) were determined according to Chiesa et al. (2011). Protein analysis was conducted using the micro-Kjeldahl method, according to the Normative Instruction 68 (BRASIL, 2006). The proteolysis extension index (PEI) and the proteolysis depth index (PDI) were calculated according to the following equations:

$$
\operatorname{PEI}(\%)=\frac{\text { non }- \text { casein nitrogen }(\%)}{\text { total nitrogen }(\%)} \times 100(\text { Eq. } 1)
$$

$$
\operatorname{PDI}(\%)=\frac{\text { non }- \text { protein nitrogen }(\%)}{\text { total nitrogen }(\%)} \times 100(\text { Eq. } 2)
$$




\section{Statistical analysis}

The experiment was carried out using a completely randomized design (CRD), in a $4 \times 3$ factorial scheme, comprised of two factors: factor $1\left(\mathrm{~F}^{1}\right)$ consisted of the maturation period $(1,22,43$, and 64 days) and factor $2\left(\mathrm{~F}^{2}\right)$, the type and concentration of the coagulant. The obtained data were submitted to statistical analysis using the $\mathrm{R}$ program (Version 3.2.2) (R CORE TEAM, 2017). Previously, a descriptive analysis of the data was performed, followed by the means comparison test (Tukey test at 5\% probability). In order to verify the existence and degree of relationship between the studied variables, a correlation study was conducted.

\section{RESULTS AND DISCUSSION}

\section{$\mathrm{pH}$ and moisture content}

The $\mathrm{pH}$ of the cheeses during the maturation period ranged from 5.18 to 5.43 (Table 1). It can be noted that the time $\left(\mathrm{F}^{1}\right)$ also did not influence $(\mathrm{p}>0.05)$ the $\mathrm{pH}$ of the cheeses between the $43^{\text {rd }}$ and $64^{\text {th }}$ day of maturation. This behavior was previously described by Dores (2007) while studying the physicochemical and microbiological characteristics of AMC cheese that underwent maturation at room temperature and under refrigeration. The author obtained $\mathrm{pH}$ values of 5.05 for cheeses matured at room temperature, at 22 and 64 days of maturation, with no influence of time on this variable.

The initial $\mathrm{pH}$ of the cheeses was influenced by the different types of coagulant and their concentrations, given the control, at time 1 , differed statistically $(p<0.05)$ from $\mathrm{T}^{1}$ and $\mathrm{T}^{2}$, but not from $\mathrm{T}^{3}$. In turn, at 22 days of maturation, significant differences $(p<0.05)$ were observed as the concentration of the C.C.L. coagulant increased. Afterward, $\mathrm{pH}$ stabilization was observed, with the averages of all the treatments remaining statistically equal $(p>0.05)$ until the 64th day of maturation.

Silva et al. (2011), when studying the physicochemical characteristics of Canastra cheese that had matured for eight days, verified $\mathrm{pH}$ indexes ranging from 5.12 to 5.36. In addition, Resende (2010) reported an

Table $1-\mathrm{pH}$ and moisture content $(\%)$ of traditional Artisanal Minas Canastra cheese and Artisanal Minas Canastra cheese produced with Cynara cardunculus L. at different stages of maturation

\begin{tabular}{cccccc}
\hline Days & & 1 & 22 & 43 & 64 \\
\hline $\mathrm{pH}$ & $\mathrm{C}$ & $5.43^{\mathrm{aA}}$ & $5.40^{\mathrm{aA}}$ & $5.31^{\mathrm{abA}}$ & $5.21^{\mathrm{bA}}$ \\
& $\mathrm{T}^{1}$ & $5.27^{\mathrm{abC}}$ & $5.31^{\mathrm{aAB}}$ & $5.29^{\mathrm{abA}}$ & $5.18^{\mathrm{bA}}$ \\
& $\mathrm{T}^{2}$ & $5.29^{\mathrm{abC}}$ & $5.27^{\mathrm{aB}}$ & $5.26^{\mathrm{aA}}$ & $5.23^{\mathrm{aA}}$ \\
& $\mathrm{T}^{3}$ & $5.41^{\mathrm{aAB}}$ & $5.23^{\mathrm{bB}}$ & $5.38^{\mathrm{aA}}$ & $5.30^{\mathrm{abA}}$ \\
\hline Moisture & $\mathrm{C}$ & $43.72^{\mathrm{aA}}$ & $20.72^{\mathrm{bA}}$ & $16.40^{\mathrm{cA}}$ & $16.78^{\mathrm{cA}}$ \\
& $\mathrm{T}^{1}$ & $44.70^{\mathrm{aA}}$ & $20.23^{\mathrm{bA}}$ & $16.72^{\mathrm{cA}}$ & $17.64^{\mathrm{bcA}}$ \\
& $\mathrm{T}^{2}$ & $46.25^{\mathrm{aA}}$ & $14.63^{\mathrm{cB}}$ & $11.65^{\mathrm{cB}}$ & $18.01^{\mathrm{bA}}$ \\
& $\mathrm{T}^{3}$ & $44.62^{\mathrm{aA}}$ & $15.70^{\mathrm{bB}}$ & $10.57^{\mathrm{cB}}$ & $18.52^{\mathrm{bA}}$ \\
\hline
\end{tabular}

Different superscript lowercase letters in the rows and uppercase letters in the columns denote that the means differ between each other $(\mathrm{p}<0.05)$, which columns refer to coagulant concentration and the rows refer to time maturation. $\mathrm{C}=$ Control; $\mathrm{T}^{1}=$ treatment $1\left(0,4 \mathrm{~g} \cdot \mathrm{L}^{-1}\right) ; \mathrm{T}^{2}=$ treatment $2\left(0,6 \mathrm{~g} \cdot \mathrm{L}^{-1}\right) ; \mathrm{T}^{3}=\operatorname{treatment} 3\left(0,8 \mathrm{~g} \cdot \mathrm{L}^{-1}\right)$. 
average $\mathrm{pH}$ value of 5.35 for Artisanal Minas Canastra cheeses matured between seven and fifteen days, at an altitude above 1,000 $\mathrm{m}$. These results corroborate the $\mathrm{pH}$ range of the cheeses obtained in the present study. The initial variability in $\mathrm{pH}$ values may have a close relationship with cheese mass pressing since, in this step, a large portion of lactose may be retained (FURTADO, 1991). The manual pressing applied to the Artisanal Minas Canastra cheese denotes the possibility of the occurrence of such variations. Also, the stabilization period might be related to buffering compounds, such as proteins and peptides produced during maturation.

Regarding moisture content, according to the Brazilian technical regulation on cheese identity and quality (BRASIL, 1996), at time 1 , the cheeses were classified as having medium moisture, with the exception of $\mathrm{T}^{2}$, which reached values higher than $46 \%$. However, 22 days after manufacturing, all of the cheeses could be reclassified as lowmoisture cheeses, with moisture content less than 36\% (BRASIL, 1996). The considerable moisture loss of the cheeses during the first days coincides with the reduction in the region's rainfall index (16.3 $\mathrm{mm}$ to $1.7 \mathrm{~mm})$, which occurred from April to May 2016, respectively, during the experiment (INMET, 2016).

Silva et al. (2011) and Resende (2010) evaluated Canastra cheeses that matured for 8 days, and between 7 and 15 days, respectively. The authors classified the cheeses as presenting medium moisture due to the short period used for maturation. Oliveira et al. (2013), when evaluating the physicochemical characteristics of Canastra cheese, also classified the cheeses as exhibiting medium moisture, although the authors did not specify the duration of the maturation period. A study developed by Dores (2007) assessed Canastra cheeses that were matured during
64 days at a temperature of $27^{\circ} \mathrm{C}$ and $68 \%$ relative humidity $(\mathrm{RH})$, simulating a rainy period, and $23{ }^{\circ} \mathrm{C}$ and $62 \%(\mathrm{RH})$, simulating a dry period. The author classified the cheeses at 22 days as exhibiting low moisture, under the two proposed conditions. Nonetheless, the moisture percentages described by the author $(32.49 \%$ and $34.54 \%$, respectively) were considerably closer to the classification range for low-moisture cheeses $(36 \%)$. These percentages are far above those proposed in the present study regarding the same period. The overall results indicate the existence of independent factors during the maturation of cheeses during manufacturing (variations in temperature, relative humidity, air flow, etc.), regardless of the simulated conditions.

During the first 22 days of maturation, a decrease in the moisture content of the cheeses was verified, and similar behavior was observed between the control and $\mathrm{T}^{1}, \mathrm{~T}^{2}$ and $\mathrm{T}^{3}$; the latter treatments showed a slight increase in moisture at the end of the analyzed period. This behavioral similarity may be related to the microstructure of the cheeses. As proposed by Delgado et al. (2015), cheeses manufactured with Cynara cardunculus L. tend to develop a softer texture when compared to those produced with other types of coagulant, influencing the greater or lesser release of free water into the cheese, translated by the equilibrium relative humidity - ERH (DAMORAN et al., 2010).

Regarding factor $2\left(\mathrm{~F}^{2}\right)$, at time 1, differences concerning the moisture of the cheeses were not verified $(p>0.05)$. However, when analyzing this parameter between the $22^{\text {nd }}$ and $43^{\text {rd }}$ day of maturation, $\mathrm{T}^{1}$ and the control treatment were statistically identical, differing from $\mathrm{T}^{2}$ and $\mathrm{T}^{3}(\mathrm{p}<0.05)$, which did not exhibit significant differences $(p>0.05)$ between each other. On the other hand, at 64 days, the means of all of the treatments were statistically the same $(\mathrm{p}>0.05)$. 


\section{Texture}

In general, the control displayed considerably atypical behavior when compared with the other treatments (Table 2), given there was a gradual increase in firmness over time, which was not observed in the cheeses produced with Cynara cardunculus L. Treatments $\mathrm{T}^{2}$ and $\mathrm{T}^{3}$ stood out since they exhibited a decline regarding the variable during the first 43 days of maturation, reinforcing the hypothesis that cheeses produced with the plant extract retain a lighter texture.

Considering factor $2\left(\mathrm{~F}^{2}\right)$, at time 1 , the average firmness content of the $\mathrm{C}$ did not differ statistically from the other treatments ( $p>0.05)$, and, at 22 days, they were statistically identical. Nevertheless, as the concentration of Cynara cardunculus L. increased, significant differences were observed between the $\mathrm{C}$ and the other treatments, from the $43^{\text {rd }}$ to the $64^{\text {th }}$ day of maturation, except for the equivalence between the control and $\mathrm{T}^{2}$ at 64 days. These results suggest that the cheeses produced with coagulant from Cynara cardunculus L. tend to deve- lop a more homogeneous structure, enhancing creaminess and conveying more lightness to the cheese, characteristics which are inversely proportional to firmness (DELGADO et al., 2015). The analysis of the moderate negative correlation $(-0.43)$ between the firmness and PEI variables, observed in the present study, reinforces such hypothesis.

Data regarding the texture profile of $\mathrm{AMC}$ cheese was not found in the literature. Correia et al. (2016), while assessing the effects of different ecotypes of cardoon flowers applied in the coagulation of milk used for the manufacture of Serra da Estrela cheese, matured for 15 to 20 days at a temperature of $7-8{ }^{\circ} \mathrm{C}$, and for a further 20 to 25 days at $10-12{ }^{\circ} \mathrm{C}$, reported firmness values ranging from 2.4 to $5.6 \mathrm{~N}$. These values were well below the firmness parameters obtained in the present study, in which a higher concentration of the plant coagulant was utilized.

Meanwhile, maturation under controlled temperatures and relative humidity resulted in cheeses with higher moisture content $(80$ to $85 \%$ ), thus, with a higher percentage of

Table 2 - Texture parameters: firmness and fracturing of the traditional Artisanal Minas Canastra cheese and Artisanal Minas Canastra cheese produced with Cynara cardunculus L., at different stages of maturation

\begin{tabular}{cccccc}
\hline Days & & 1 & 22 & 43 & 64 \\
\hline \multirow{2}{*}{ Firmness (N) } & $\mathrm{C}$ & $4.70^{\mathrm{bAB}}$ & $5.92^{\mathrm{abA}}$ & $6.47^{\mathrm{abA}}$ & $7.15^{\mathrm{aAB}}$ \\
& $\mathrm{T}^{1}$ & $4.47^{\mathrm{bB}}$ & $4.71^{\mathrm{bA}}$ & $3.78^{\mathrm{bB}}$ & $8.17^{\mathrm{aA}}$ \\
& $\mathrm{T}^{2}$ & $6.66^{\mathrm{aAB}}$ & $4.36^{\mathrm{bA}}$ & $3.70^{\mathrm{bB}}$ & $5.66^{\mathrm{abBC}}$ \\
& $\mathrm{T}^{3}$ & $6.88^{\mathrm{aA}}$ & $3.86^{\mathrm{bA}}$ & $3.31^{\mathrm{bB}}$ & $4.92^{\mathrm{abC}}$ \\
\hline \multirow{3}{*}{ Fracturing $(\mathrm{N})$} & $\mathrm{C}$ & $4.70^{\mathrm{bAB}}$ & $5.89^{\mathrm{abA}}$ & $7.12^{\mathrm{aA}}$ & $7.02^{\mathrm{aAB}}$ \\
& $\mathrm{T}^{1}$ & $4.43^{\mathrm{bB}}$ & $4.71^{\mathrm{bA}}$ & $3.72^{\mathrm{bB}}$ & $7.86^{\mathrm{aA}}$ \\
& $\mathrm{T}^{2}$ & $6.66^{\mathrm{aAB}}$ & $4.36^{\mathrm{bA}}$ & $3.70^{\mathrm{bB}}$ & $5.63^{\mathrm{abAB}}$ \\
& $\mathrm{T}^{3}$ & $6.88^{\mathrm{aA}}$ & $3.86^{\mathrm{bA}}$ & $3.31^{\mathrm{bB}}$ & $4.89^{\mathrm{abB}}$ \\
\hline
\end{tabular}

Different superscript lowercase letters in the rows and uppercase letters in the columns denote that the means differ between each other $(\mathrm{p}<0.05)$, which columns refer to coagulant concentration and the rows refer to time maturation. $\mathrm{C}=$ Control; $\mathrm{T}^{1}=$ treatment $1\left(0,4 \mathrm{~g} \cdot \mathrm{L}^{-1}\right) ; \mathrm{T}^{2}=$ treatment $2\left(0,6 \mathrm{~g} \cdot \mathrm{L}^{-1}\right) ; \mathrm{T}^{3}=$ treatment $3\left(0,8 \mathrm{~g} \cdot \mathrm{L}^{-1}\right)$. 
free water, favoring enzymatic activity. Also, the intense proteolysis observed in cheeses produced with sheep's milk promotes the maintenance of a lighter texture (SOUSA; MALCATA, 1997).

Pinto et al. (2011) evaluated the effects of nisin on Staphylococcus aureus count and the physicochemical properties of Artisanal Minas Serro cheese, matured during 7, 14, 30,45 , and 60 days. The control cheese used in the mentioned study displayed firmness parameters of $135.04 \mathrm{~N}$ at 14 days, and $38.47 \%$ humidity. At 22 days of maturation, even with $20.72 \%$ moisture content, the AMC cheese (C) exhibited a firmness value of $59.19 \mathrm{~N}$. These results show the influence of edaphoclimatic and methodological specificity on the different regions of Artisanal Minas cheese production. In addition, the $\mathrm{T}^{1}, \mathrm{~T}^{2}$, and $\mathrm{T}^{3}$ treatments also displayed firmness parameters that were much inferior to that of Serro cheese.

The cheese fracturing parameter showed very similar behavior to firmness, which was highlighted by the correlation analysis (0.99). A gradual increase of the variable in the first 43 days of maturation was observed regarding the control, albeit not in the treatments. Such behavior indicates that cheeses produced using Cynara cardunculus L. do not become brittle in the first month of maturation, implying the maintenance of texture throughout the exposure period. The fracturing property of Artisanal Minas Serro cheese, matured for 30 days, reached 115.61 N, corroborating with what was proposed by Pinto et al. (2011). This value was lower than that of the cheese fracturing parameter $(71.19 \mathrm{~N})$ obtained with the Artisanal Minas Canastra cheese $(\mathrm{C})$ characterized in the present study.

\section{Proteolysis}

The extension rate of proteolysis (PEI) at time 1 differed from the other periods regarding all of the treatments $(\mathrm{p}<0.05)$, except for the control, at 22 days (Table 3 ). The influence of time, as of the $22^{\text {nd }}$ day of maturation, was not observed $(\mathrm{p}>0.05)$. Differences between the control and the other treatments during the first 22 days were verified $(\mathrm{p}<0.05)$. At 43 days of maturation, the

Table 3 - Proteolysis extension and depth indices (\%) of traditional Artisanal Minas Canastra cheese and Artisanal Minas Canastra cheese produced with Cynara cardunculus L., at different stages of maturation

\begin{tabular}{cccccc}
\hline Days & & 1 & 22 & 43 & 64 \\
\hline PEI & $\mathrm{C}$ & $9.59^{\mathrm{bB}}$ & $13.76^{\mathrm{abB}}$ & $18.72^{\mathrm{aC}}$ & $15.64^{\mathrm{aC}}$ \\
& $\mathrm{T}^{1}$ & $16.36^{\mathrm{bA}}$ & $25.35^{\mathrm{aA}}$ & $23.83^{\mathrm{aBC}}$ & $25.25^{\mathrm{aB}}$ \\
& $\mathrm{T}^{2}$ & $17.49^{\mathrm{bA}}$ & $23.48^{\mathrm{aA}}$ & $27.92^{\mathrm{aAB}}$ & $28.82^{\mathrm{aAB}}$ \\
& $\mathrm{T}^{3}$ & $15.76^{\mathrm{bA}}$ & $28.21^{\mathrm{aA}}$ & $32.01^{\mathrm{aA}}$ & $32.62^{\mathrm{aA}}$ \\
\hline PDI & $\mathrm{C}$ & $9.93^{\mathrm{aA}}$ & $9.43^{\mathrm{aB}}$ & $13.21^{\mathrm{aB}}$ & $12.80^{\mathrm{aB}}$ \\
& $10.65^{\mathrm{bA}}$ & $13.52^{\mathrm{abAB}}$ & $17.29^{\mathrm{aAB}}$ & $17.47^{\mathrm{aA}}$ \\
& $\mathrm{T}^{1}$ & $15.22^{\mathrm{bA}}$ & $18.84^{\mathrm{abA}}$ & $19.87^{\mathrm{aA}}$ \\
& $\mathrm{T}^{2}$ & $10.40^{\mathrm{cA}}$ & $13.84^{\mathrm{bA}}$ & $19.96^{\mathrm{aA}}$ & $21.43^{\mathrm{aA}}$ \\
\hline
\end{tabular}

Different superscript lowercase letters in the rows and uppercase letters in the columns denote that the means differ between each other $(\mathrm{p}<0.05)$, which columns refer to coagulant concentration and the rows refer to time maturation. $\mathrm{C}=$ Control; $\mathrm{T}^{1}=$ treatment $1\left(0,4 \mathrm{~g} \cdot \mathrm{L}^{-1}\right) ; \mathrm{T}^{2}=$ treatment $2\left(0,6 \mathrm{~g} \cdot \mathrm{L}^{-1}\right) ; \mathrm{T}^{3}=$ treatment $3\left(0,8 \mathrm{~g} \cdot \mathrm{L}^{-1}\right)$. 
C treatment did not differ from $T^{1}(p>0.05)$, although differences were observed when the concentration of Cynara cardunculus L. increased $(p<0.05)$. On the 64 th day of maturation, the control differed from $\mathrm{T}^{1}, \mathrm{~T}^{2}$, and $\mathrm{T}^{3}$ regarding the PEI $(\mathrm{p}<0.05)$. This result suggests that, in comparison with animal rennet, the use of plant coagulant for milk coagulation considerably raised the rates of proteolysis extension (SOUSA; MALCATA, 1997; ROA et al., 1999). The concentration of C.C.L. did not influence the PEI during maturation $(\mathrm{p}>0.05)$.

Sousa and Malcata (2002) developed studies on the performance of plant coagulant from Cynara cardunculus L. in cheeses produced with milk from different animal species. Those manufactured with bovine milk presented $32.9 \%$ PEI at 68 days of maturation, which was consistent with the $32.2 \%$ PEI obtained in the present study, at 64 days, regarding $\mathrm{T}^{3}$. Roa et al. (1999) described proteolysis extension rates in Spanish cheeses (La Serena), produced with raw sheep's milk coagulated with Cynara cardunculus L., in the order of $21.4 \%$ (at 0 days) and $32.9 \%$ (at 30 days of maturation). At time 0 , the obtained result was compatible with the PEI described at 64 days of maturation of AMC cheese produced with $0.8 \mathrm{~g}$ of C.C.L.L ${ }^{-1}$ of milk. The concentration of Cynara cardunculus L. used by Roa et al. (1999) was of 1.6 g.L.1, which explains the high rates of proteolysis reported in the experiment. Delgado et al. (2015), when analyzing the physicochemical characteristics, proteolysis, and texture of the Spanish cheese Torta del Casar, also produced with sheep's milk, and coagulated with Cynara cardunculus L., verified a PEI of $42.28 \%$ at 60 days of maturation. The chemical composition of milk and the specificity of Cynara cardunculus L., regarding ovine casein and C.C.L. in milk coagulation, may be directly related to its intense proteolysis activity (GALÁN et al., 2008; GUERRA et al., 2008).
The proteolysis depth index (PDI) did not show significant variations during the maturation of the control. For $\mathrm{T}^{1}$, time 1 was statistically equal to time 22 , although it differed in the following periods. Regarding $\mathrm{T}^{2}$, time 1 was observed to be statistically different from times 22, 43, and 64. In turn, for $\mathrm{T}^{3}$, no differences between times 1 and 22 were verified, although they differed from periods 43 and 64, which were statistically equal. The PDI did not change when using the different coagulants at time 1. However, at 22 days, the control varied in relation to $\mathrm{T}^{2}$ and $\mathrm{T}^{3}$, but not from $\mathrm{T}^{1}$. Similar behavior was observed on the $43^{\text {rd }}$ day of maturation. On day 64, such behavior no longer occurred, and the control differed from all the other treatments. The Pearson correlation test showed a potentially negative correlation between moisture content and the proteolysis extension and depth indices (-0.64 and -0.66 , respectively). Higher values of moisture implied reduced proteolysis products.

A gradual increase in PEI was observed for $\mathrm{T}^{2}$ and $\mathrm{T}^{3}$ during maturation. In turn, regarding $T^{1}$, the parameter increased until the $22^{\text {nd }}$ day, followed by a decrease and subsequent increase as of the $43^{\text {rd }}$ day of maturation. The control showed a milder PEI (85\% lower than $\mathrm{T}^{1}$ ), increasing gradually until the $22^{\text {nd }}$ day, which was followed by a reduction in value. Galán et al. (2008), when applying $0.2 \mathrm{~g}$ and $0.4 \mathrm{~g}$ of Cynara cardunculus L. in the manufacturing of cheeses produced with raw sheep's milk, obtained proteolysis extension rates of approximately $20 \%$ and $40 \%$, respectively, at 30 days of maturation. This behavior was not observed during the evaluation of the AMC cheese, in which the PEI did not double when the concentration of Cynara cardunculus L. increased by $100 \%$. These results denote the specificities in the performance of the plant coagulant regarding the type of milk used to manufacture the cheeses. 
Sousa and Malcata (2002) reported significant differences in the primary proteolysis index of cheeses produced with Cynara cardunculus L. from sheep, goat, and cow milk. Primary proteolysis was more intense in cheeses produced using sheep's milk $(11.9 \%)$ than those made with goat milk $(8.28 \%)$ and cow milk (6.59\%). However, at 68 days of maturation, the percentage of soluble nitrogen was higher for cheeses produced with goat milk (48.7\%) than those obtained with sheep (46.4\%) and cow (32.9\%) milk.

O’Mahony et al. (2003) verified proteolysis extension indices in small slices of Cheddar cheese produced with Cynara cardunculus L., in the order of $8.03 \%$, at 30 days of maturation, lower than the means described in the present study. The use of pasteurized milk and maturation at controlled temperatures possibly influenced the proteolysis behavior during the storage of the cheeses (SOUSA; MALCATA, 2002). Silva et al. (2011), when studying the physicochemical characteristics of Canastra cheese matured for eight days, showed a range of $9.26 \%$ and $12.80 \%$ of PEI and PDI, respectively. These results corroborate those reported in the present study during the initial days of control maturation, with the exception of PDI, which was $24 \%$ lower. The adoption of hygienic and sanitary measures over time, in addition to the particularities observed throughout cheese manufacturing, may have contributed to the reduction in the active microbiota and, consequently, to the decrease in PDI verified herein.

Dores (2007), while studying the physicochemical and microbiological characteristics of Artisanal Minas Canastra cheese matured at room temperature and under refrigeration, reported a PEI of $12.95 \%$ and $14.63 \%$ at 22 and 64 days of maturation, respectively, during the rainy season. This percentage was slightly lower than the PEI values of $13.76 \%$ and $15.64 \%$ proposed in the present study for the control during the same period. The concentration and amount of coagulant applied may explain this small discrepancy. On the other hand, the PDI values described by Dores (2007), for the same period, were $9.58 \%$ and $12.43 \%$. Such index is consistent with the percentage of proteolysis depth $(9.43 \%$ and $12.80 \%)$ observed in the present study, which denotes the direct influence of the endogenous culture on this variable.

Regarding PDI, $\mathrm{T}^{1}, \mathrm{~T}^{2}$, and $\mathrm{T}^{3}$ showed higher intensity, with a decrease in $\mathrm{T}^{1}$ only after the $43^{\text {rd }}$ day. Nevertheless, the concentration of Cynara cardunculus L. did not statistically influence the PDI during maturation. In turn, the control displayed a milder PDI, with a slight decrease and subsequent increase between the $43^{\text {rd }}$ and $64^{\text {th }}$ day of maturation. Galán et al. (2008) reported that the increment in the proteolytic activity of casein in cheeses produced with Cynara cardunculus L. resulted in an increase in the non-protein nitrogen content used as a substrate for lactic-acid bacteria activity, thus enhancing the proteolysis depth index.

\section{CONCLUSIONS}

The Artisanal Minas Canastra cheese produced with Cynara cardunculus L. exhibited superior proteolysis extension and depth indices when compared to the traditional Canastra cheese. The $\mathrm{pH}$ and moisture content were not influenced by the type of coagulant, although they varied during maturation. Also, the cheeses obtained with the C.C.L. coagulant displayed a softer texture when compared with the traditional cheese, even after 42 days of maturation. These results indicate the possibility of producing cheeses with desirable sensory characteristics within the minimum required maturation period, thus increasing the diversity of 
supply and promoting the appreciation of the artisanal product with certification of origin.

\section{ACKNOWLEDGEMENTS}

We acknowledge Mr. Wander Evangelista de Carvalho (in memory) and Mrs. Marisa de Lima Carvalho, owners of the Boa Vista farm. We also thank researcher Paulo Barracosa, from the Viseu School of Agriculture, and the technician Gabriel Tôrres, an extensionist from Emater/MG, in Tapiraí-MG.

\section{REFERENCES}

ALMEIDA, E. F. L.; FERNANDES, M. R. Caracterização da Microrregião da Canastra como produtora de queijo Minas artesanal. EMATER-MG. São Roque de Minas, 2004.

AMMAR, I. B.; SONNANTE, G.; DRIDI, B. AL M. Genetic variability in wild cardoon (Cynara cardunculus L. var. silvestris) revealed by SSR makers and morphological traits. Scientia Horticulturae, v. 185, p. 7681, 2015.

ASSOCIAÇÃO DOS PRODUTORES DE QUEIJO CANASTRA (APROCAN). Regulamento de uso. Estatuto Social da Aprocan. Sistema FAEMG, 2014.

BRASIL. Mistério do Desenvolvimento, Indústria e Comércio Exterior. Instrução Normativa $n^{0} 25$, de 21 de agosto de 2013. Estabelece as condições para o registro das Indicações Geográficas. Diário Oficial da República Federativa do Brasil, Brasília, 2013.

BRASIL. Ministério da Agricultura, Pecuária e Abastecimento. Instrução Normativa $\mathrm{n}^{\mathrm{o}}$ 68, de 12 de dezembro de 2006. Oficia- liza os métodos analíticos oficiais físicoquímicos, para controle de leite e produtos lácteos, em conformidade com o anexo desta Instrução Normativa, determinando que sejam utilizados nos laboratórios nacionais agropecuários. Diário Oficial da República Federativa do Brasil, Brasília, 2006.

BRASIL. Ministério da Agricultura e do Abastecimento. Portaria $\mathrm{n}^{\circ} 146$, de 07 de março de 1996. Secretaria Nacional de Inspeção de Produtos de Origem Animal. Regulamento Técnico de Identidade e Qualidade dos Produtos Lácteos. Diário Oficial da República Federativa do Brasil, Brasília, 1996.

CHIESA, M. O. et al. Avaliação da composição química, proteólise e propriedades funcionais do queijo muçarela comercial com teor reduzido de gordura. Revista do Instituto de Laticínios Candido Tostes, v. 326, n. 57, p. 28-33, 2011.

CORREIA, P. et al. Effect of different thistle flower ecotypes as milk-clotting in Serra da Estrela cheese. Nutrition and Food Science, v. 46, n. 4, p. 458-475, 2016.

DAMODARAM, S.; PARKIN, K. L.; FENNEMA, O. R. Química de Alimentos de Fennema. $4^{\mathrm{a}}$ ed. Porto Alegre: Artmed, 2010. 900 p.

DELGADO, F. J et al. Physicochemical, proteolysis and texture changes during the storage of a mature soft treated by high-pressure hydrostatic. European Food Research and Technology, v. 240, p. 1167-1176, 2015.

DORES, M. T. Queijo Minas Artesanal da Canastra maturado à temperatura ambiente e sob refrigeração. 2007. 91 p. Dissertation (Masters in Food Science and Technology) - Universidade Federal de Viçosa, Viçosa, 2007. 
FURTADO, M. M. A arte e a ciência do queijo. São Paulo: Globo, 1991. 297 p.

GALÁN, E. et al. Influence of different amounts of vegetable coagulant from cardoon Cynara cardunculus and calf rennet on the proteolysis and sensory characteristics of cheeses made with sheep milk. International Dairy Journal, v. 18, p. 93-98, 2008.

GUERRA, I. C. D. et al. Análise comparativa da composição centesimal de leite bovino, caprino e ovino. In: ENCONTRO DE INICIAÇÃO À DOCÊNCIA, 10., 2008, João Pessoa. Anais eletrônicos... João Pessoa: UFPB, 2008 Available from: <http:// www.prac.ufpb.br/anais/IXEnex/iniciacao/ documentos/anais/6.SAUDE/6CCSDNMT10. pdf $>$. Accessed in October, 2016.

INSTITUTO NACIONAL DE METEOROLOGIA (INMET). Estação Climatológica Principal de Bambuí/MG, 2016.

INSTITUTO MINEIRO DE AGROPECUÁria (IMA). Portaria $\mathbf{n}^{\mathbf{0}} \mathbf{1 . 3 0 5}$, de 30 de abril de 2013. Estabelece diretrizes para a produção de queijo Minas artesanal. Belo Horizonte, 2013.

INSTITUTO MINEIRO DE AGROPECUÁRIA (IMA). Portaria n. ${ }^{\circ} 546$, de 29 de outubro de 2002 . Identifica a microrregião do Serro como produtora do queijo Minas artesanal. Belo Horizonte, 2002.

INSTITUTO MINEIRO DE AGROPECUÁRIA (IMA). Portaria n. ${ }^{\circ}$ 594, de 10 de junho de 2003. Identifica a microrregião de Araxá como produtora do queijo Minas artesanal. Belo Horizonte, 2003.

INSTITUTO MINEIRO DE AGROPECUÁRIA (IMA). Portaria n. ${ }^{\circ}$ 694, de 17 de novembro de 2004. Identifica a microrregião da Canastra como produtora do queijo Minas artesanal. Belo Horizonte, 2004.

INSTITUTO MINEIRO DE AGROPECUÁRIA (IMA). Portaria n. ${ }^{\circ}$ 874, de 02 de outubro de 2007. Altera a denominação da microrregião do Alto Paranaíba como produtora do queijo Minas artesanal. Belo Horizonte, 2007.

INSTITUTO MINEIRO DE AGROPECUÁRIA (IMA). Portaria n. ${ }^{\circ} \mathbf{1 0 2 2}$, de 03 de novembro de 2009. Identifica a microrregião do Campo das Vertentes como produtora do queijo Minas artesanal. Belo Horizonte, 2009.

INSTITUTO MINEIRO DE AGROPECUÁRIA (IMA). Portaria n. ${ }^{\circ}$ 1397, de 13 de fevereiro de 2014. Identifica a microrregião Triângulo Mineiro como produtora do queijo Minas artesanal. Belo Horizonte, 2014a.

INSTITUTO MINEIRO DE AGROPECUÁRIA (IMA). Portaria n. ${ }^{\circ} \mathbf{1 4 2 8}$, de 29 de agosto de 2014. Identifica a microrregião da Serra do Salitre como produtora do queijo Minas artesanal. Belo Horizonte, 2014b.

MARABUTO, E. et al. Cynara cardunculus L. - mapa de distribuição. Flora-On: Flora de Portugal Interactiva, Sociedade Portuguesa de Botânica, 2015. Available in: <http:// www.flora-on.pt/\#wCynara+cardunculus $>$. Accessed on: 31 aug. 2015.

MATOS, L. A. I. O conhecimento regional do queijo minas artesanal na indicação geográfica de procedência Canastra: ensinando o padre a rezar. 2016. $274 \mathrm{f}$. Thesis (Doctorate) Universidade Federal do Rio de Janeiro, Rio de Janeiro, 2016.

OLIVEIRA, D. F. et al. Caracterização físico-química de queijos Minas artesanal 
produzidos em diferentes microrregiões de Minas Gerais. Revista Brasileira de Economia Domés tica, v. 24, n. 2, p. 185-196, 2013 .

O'MAHONY, J. A.; SOUSA, M. J.; MCSWEENEY, P. L. H. Proteolysis in miniature Cheddar-type cheeses made using blends of chymosin and Cynara cardunculus proteinases as coagulant. International Journal of Dairy Technology, v. 56, n. 1, p. 52$58,2003$.

PINTO, M. S. et al. The effects of nisin on Staphylococcus aureus count and the physicochemical properties of Traditional Minas Serro cheese. International Dairy Journal, v. 21, p. 90-96, 2011.

RESENDE, Maria F. S. de. Queijo Minas artesanal da Serra da Canastra: Influência da altitude e do nível de cadastramento das queijarias nas características físicoquímicas e microbiológicas. 2010. 72 p. Dissertation (Masters in Animal Science) Universidade Federal de Minas Gerais, Belo Horizonte, 2010.

ROA, I.; LÓPEZ, M. B.; MENDIOLA, F. J. Residual clotting activity and ripening properties of vegetable rennet from Cynara cardunculus in La Serena cheese. Food
Research International, v. 32, p. 413-419, 1999.

SILVA, J. G. Características físicas, físico-químicas e sensoriais do queijo Minas artesanal da Canastra. 2007. 198 p. Dissertation (Masters in FoodSciences) - Universidade Federal de Lavras, Lavras, 2007.

SILVA, J. G. Características físico-químicas do queijo Minas artesanal da Canastra. Revista do Instituto de Laticínios Cândido Tostes, v. 66, n. 380, p. 16-22, 2011.

SOUSA, M. J.; MALCATA, F. X. Comparison of plant and animal rennets in terms of microbiological, chemical and proteolysis characteristics of ovine cheese. Journal of Agricultural Food Chemistry, v. 45, p. 7481, 1997.

SOUSA, M. J.; MALCATA, F. X. Advances in the role of a plant coagulant (Cynara cardunculus) in vitro and during ripening of cheeses from several milk species. Lait, v. 82, p. 151-170, 2002.

TOFALO, R. et al.; Influence of pig rennet on proteolysis, organic acids content and microbiota of Pecorino de Farindola, a traditional Italian ewe's raw milk cheese. Food Chemistry, v. 175, p. 121-127, 2015. 